\title{
Work-life balance among newly employed officers - a qualitative study
}

\section{BACKGROUND}

A military career puts great demands on the individual as regards combining working life and private life. The military and the family both demand time, energy, engagement, and commitment from the individual. Finding an appropriate balance between work and non-work might be particularly complex during military training and deployments that require extended periods away from home. The aim of this study was to investigate newly employed officers' perceptions of work-life balance and its implications for future careers.

\section{PARTICIPANTS AND PROCEDURE}

This article is based on 34 semi-structured interviews with newly employed officers and non-commissioned officers in the Swedish Armed Forces (SAF). The interviews were analyzed according to the six-phase approach of coding and theme development by thematic analysis.

\section{RESULTS}

The analysis resulted in the emergence of three main themes: coping with different loyalties, individual and or- ganizational strategies, and concerns about the future. All officers expressed loyalty to their work and organization, but these perceptions were influenced by significant others in private life. High ambitions in combination with stressful working conditions made organizational supportive strategies important, but these differed between units. Concerns about a constantly high workload and lack of recovery were highlighted, as well as concerns about future career and family building.

\section{CONCLUSIONS}

In order to retain qualified personnel, the SAF should provide support and create conditions that help employees to balance work and non-work. A career in the Armed Forces will inevitably entail a reduced work-life balance, and our results show that the newly employed officers are highly aware of this. To ease the pressure, the SAF could be clearer about the expectations on their new employees.

\section{KEY WORDS}

work-life balance; career; military officers 


\section{BACKGROUND}

A military career puts great demands on the individual with regard to work-life balance. The military and the family could be considered greedy institutions since both demand time, energy, engagement, and commitment from the individual (Segal, 1986). Duty personnel must be ready to participate in unpredictable and stressful situations at all times, usually with little or no advance notice (MacDermid \& Southwell, 2011). In addition, military personnel faces frequent separations from family and friends due to requirements to participate in training, education, and national or international operations (Pickering, 2017). Finding an appropriate balance between work and non-work might be particularly complex during military training and deployments that require extended periods away from home.

Military personnel's perceptions of work-life balance are likely to influence their attitudes towards job satisfaction and turnover intentions (Sachau et al., 2012), and receiving organizational support, and thereby getting better equipped to deal with the conflicting demands of work and non-work, has a positive impact on job satisfaction and reduces turnover intentions (Dupré \& Day, 2007; Anderson \& Goldenberg, 2019). Consequently, work-life balance in the military context is a highly relevant, yet understudied issue that calls for more attention.

The Swedish Armed Forces (SAF) is in the midst of a new strategic direction. The organization is expected to grow, and the focus has shifted from international missions to national defense (Österberg \& Nilsson, 2019). More conscripts are being called in, and an increasing number of individuals are attending officer training. Contemporarily, the SAF is facing significant challenges due to many retirements in the years to come. This expansion of the SAF has consequences for the new officers, entering an organization full of vacancies, meaning that several newly graduated officers might experience a high workload (Österberg et al., submitted). The current situation highlights the importance of investigating recently graduated officers' perceptions of work-life balance.

\section{WORK-LIFE BALANCE}

Work-life balance is a well-established concept that has been extensively studied in previous research (e.g. Clark, 2000; Greenhaus et al., 2003; Hill et al., 2001; Voydanoff, 2005). Balance relates to the job, life, and family satisfaction, as research on work-life balance aims to explain how well employees succeed in combining their work roles and non-work roles (Casper et al., 2018). There are different designations in the literature, aiming at conceptualizing the rela- tion between the two dominant life domains of work and non-work. The concepts of 'work-life balance', 'work-family balance', 'work-home balance', or merely 'balance', are intermittently used to explain how individuals perceive and manage their work roles and non-work roles. The term 'family' is commonly used to describe the non-work domain, often irrespective of the individual having a family with a spouse and children or not. This paper will use the terms 'work' and 'life' for each domain, and the concept 'work-life balance' to explain their relationship.

Clark (2000, p. 751) defines work-life balance as "satisfaction and good functioning at work and home, with a minimum of role conflict". Her work/ family border theory provides a useful framework for understanding how individuals manage and negotiate the work and life domains and the borders between them to attain balance. According to the theory, work and home are two different domains with contrasting cultures, each consisting of specific rules and expectations about behavior. Borders between domains, defining the point at which domainrelevant behavior begins or ends, are characterized by permeability (the degree to which elements from another domain may enter) and flexibility (the extent to which a border can contract or expand). These determine how individuals separate or integrate work and home (Clark, 2000). Individuals are bordercrossers, making regular transitions between work and home domains. These transitions are affected by the individuals' influence on and identification with domain responsibilities and other domain members' (e.g. supervisors and spouses) perceptions of what constitutes work and home. In summary, the theory suggests that an individual's perception of balance is influenced by the strength of borders, identification with domains, and social support from significant others.

Work-life conflict emerges when role pressures from the work domain and the life domain are incompatible in some respect (Greenhaus \& Beutell, 1985). There are two directions of conflict: work-tolife conflict occurs when work interferes with private life, and life-to-work conflict occurs when private life interferes with work (Frone et al., 1997). Most research has assessed only work-to-family conflict, since interference of work demands with private life has a more significant impact on perceived conflict and is a better predictor of reduced job satisfaction and increased turnover intentions (e.g. Sachau et al., 2012).

Three primary causes of conflict are discussed in the literature. Time-based conflict emerges when time engaged in one role makes it difficult to fulfill the obligations of another role (Greenhaus \& Beutell, 1985). Long work hours, overtime, and irregularity or inflexibility of work schedule are examples of workrelated issues that could contribute to a time-based 
conflict (Huffman et al., 2014; Pleck et al., 1980). The second source of conflict, strain-based conflict, applies when strain in one role affects the individual's performance in another (Greenhaus \& Beutell, 1985). Work stressors that lead to tensions and irritability could spill over to the life domain, and vice versa concerning life stressors. Behavior-based conflict occurs when specific behaviors are required in one role, making it challenging to meet the requirements of another role (Greenhaus \& Beutell, 1985). Behavioral expectations from peers and supervisors at work could include hardiness, emotional stability, and straightforwardness. At the same time, spouses, children, and friends, on the other hand, wish the individual to be warm, emotional, and vulnerable.

So far, only situational demands have been considered causing interference between work and private life. In addition, personal variables could serve as significant predictors of work-life conflict. Research shows that negative affect, neuroticism and low selfefficacy are reported as risk factors, whereas optimism, positive affect, and self-efficacy are considered protective factors (Allen et al., 2012). This suggests that individuals with a positive approach to life are better off handling the different demands of work and private life, and those with a negative approach are more likely to experience conflict. Furthermore, research shows that organizational support plays a vital role in helping individuals cope with work-life conflict (French et al., 2018).

\section{WORK-LIFE BALANCE IN A MILITARY CONTEXT}

Military members face unique challenges in balancing their military commitments and home-related responsibilities. Duty personnel must be prepared to attend stressful and unpredictable situations 24/7, sometimes with little or no advance notice (MacDermid \& Southwell, 2011). A longitudinal study on army soldiers showed that working long hours and experiencing role overload (the amount of energy required to complete work) had an immediate effect on their perception of work-life conflict (Huffman et al., 2014). Moreover, role overload related more strongly to work-life conflict, which indicates that e.g. irregularity of work schedule and a high workload to a greater extent contribute to perceptions of work interfering with private life.

Throughout their career, military members are likely to face repeated separations from home, family, and friends while participating in training and deployments (Pickering, 2017). After spending several months on assignments abroad, Dutch military personnel reported reduced relationship satisfaction and increased turnover intentions (Andres et al., 2012). Moreover, the personnel reporting higher work-life conflict levels also reported lower levels of satisfaction and higher turnover intentions. The authors argue that the relationship between turnover intentions and work-life conflict seems to be bidirectional, since employees thinking about leaving the job were more likely to report work interfering with their personal life. In another study, younger employees reported more work-life conflict than their older counterparts at the beginning of their careers, possibly due to their lack of previous experience of managing conflicting demands (Vuga \& Juvan, 2013). Also, more problems with balancing work and family were reported by military employees in their 30s, who had large families with dependent children.

Receiving organizational support, and thereby getting better equipped to deal with the conflicting demands of work and non-work, has a positive impact on job satisfaction and reduces leave intentions among military personnel (Anderson \& Goldenberg, 2019; Dupré \& Day, 2007; Sachau et al., 2012). A Canadian study on reservists showed that perceptions of receiving enough family support from the Armed Forces had a positive impact on overall job satisfaction and affective commitment to the organization, which reduced leave intentions (Anderson \& Goldenberg, 2019). Moreover, those who perceived more family support reported greater satisfaction with work-life balance and less work-life conflict than those experiencing less support. A similar result was found in another study, where army soldiers' perceptions of a family-friendly organizational environment were positively related to intentions to remain in the military (Huffman et al., 2008). Human resource practices such as organizational support, supervisor support, work-life balance, work stimulation, and job clarity had direct effects, as well as indirect effects through job satisfaction on health symptoms and turnover intentions among military personnel (Dupré \& Day, 2007). Consistently, Sachau et al. (2012) show that organizational support, supervisor support, and peer support for work-life balance reduced work to family conflict and family to work conflict, and both forms of conflict predicted increased turnover intentions and decreased job satisfaction.

In order to understand the relation between private life and military work in Sweden, a brief description of the Swedish military system is needed.

\section{THE SWEDISH ARMED FORCES AND OFFICER TRAINING IN SWEDEN}

The SAF has undergone some significant changes in the last decade, including leaving conscription in favor of an all-volunteer force (AVF) and then switching back to conscription (Österberg \& Nilsson, 2019). The transition to an AVF in 2010 resulted in a situation where soldiers were employed on contracts
Work-life balance among newly employed officers 
Emma Oskarsson, Johan Österberg, Joel Nilsson
(Österberg \& Rydstedt, 2018), instead of leaving the organization after completed conscription. This new situation puts job satisfaction and other work-related issues in focus (Österberg et al., 2017; Fors Brandebo et al., 2019).

Alongside converting to an AVF, the Swedish of ficer system has also undergone dramatic changes, introducing the two-category officer system. The introduction of the AVF in Sweden coincided with the renewed officer system, and after 25 years with a onecategory officer system, a two-category system with NCOs (specialists) and Officers was introduced (Hedlund, 2013). The NCOs carry out an 18-month specialist officer training, and the officers complete the 3-year academic Officers' Programme (OP). The OP is a three-year university education that leads to a bachelor level degree in War Science, and the students graduate as fänrik (second lieutenant/ensign). They lead units from platoon level and up when starting to work as officers. Specialist officers are normally educated at specialist schools and centers for 18 months and graduate as first sergeants. Experienced soldiers who have served as corporals and sergeants may take a shortened course (Österberg et al., submitted).

The introduction of the AVF followed the trend of massive downsizing of the SAF, which had been going on since the 1990s (Weber \& Österberg, 2015; Strand \& Berndtsson, 2015). The SAF struggled to recruit even a small number of soldiers (2500-4000 yearly) with the new system (Fors Brandebo et al., 2019). The re-introduction of conscription in 2018, this time gender-neutral, also brought back focus from international missions to national defense (Österberg \& Nilsson, 2019). Therefore, with this new direction for the SAF, the organization is beginning to grow again, with more conscripts being called in, and more officers starting the officer training. This expansion of the SAF has consequences for the new officers, entering an organization full of vacancies, meaning that several newly graduated officers get a high workload from day one (Österberg et al., submitted).

Moskos (1977) described how the transition from a conscripted military to an AVF in the US eventually would lead to a situation where military employment would look like employment in civilian society. The institutional orientation (which emphasizes the distinct military culture) would be replaced by an occupational orientation where salary and bonuses are appreciated. In 2010, Sweden's conscription system was suspended, and an AVF was introduced, hence introducing a new occupation into the Swedish labor market: employed soldiers (Rydstedt \& Österberg, 2013). Consequently, many officers who today serve in the SAF have their military background in the AVF, instead of in a conscription system. Job satisfaction and retention have been studied in a Swedish context during the years with an AVF (see e.g. Österberg et al., 2017; Österberg \& Rydstedt, 2018; Fors Brandebo et al.,
2019). However, work-life balance is a neglected area from a Swedish perspective. In any organization, high degrees of employee satisfaction and commitment are vital fundamentals for good work performance and employee retention. Within five years, approximately 1500 officers will retire from the SAF, which puts the work-life balance in focus.

\section{AIM OF THE STUDY}

The aim of this study is to investigate newly employed officers' perceptions of work-life balance and its implications for future careers.

\section{PARTICIPANTS AND PROCEDURE}

This article is based on semi-structured interviews with newly employed officers and non-commissioned officers in the SAF. The selection of participants was based on a convenience sample, and military contacts in four army units were asked to suggest interviewees.

A total sample of 34 participants was interviewed, of which 15 were officers ( 9 men, 6 women), and 19 were non-commissioned officers (17 men, 2 women). The gender distribution is skewed in favor of women (24\%) compared to the overall gender distribution among officers within the SAF, which comprise 9\% women. Among the participants, $12 \mathrm{had}$ a partner; only 2 had children.

The officers' ages ranged from 24 to 36 years (mean age 28 years), and they had worked as employed soldiers for roughly 1 year before starting the OP. The non-commissioned officers' ages ranged from 23 to 45 years (mean age 31 years), and they had worked as employed soldiers for about 5 years before starting the officer training. The participants had been employed as officers or specialist officers between 5 months and 4 years at the time of the interviews (mean length of service 1 year).

The interviews ranged from 30 to 73 minutes and were conducted in individual rooms at the army units. It was ensured that no one would interfere during the interviews so that the participants could speak freely. Informed consent was obtained from all participants. They were given information about the study, that their accounts would be treated confidentially, and that they had the opportunity to withdraw at any point without having to declare the reason.

The semi-structured interview guide included open-ended questions about perceptions of officer training, working conditions, work-life balance, social support, and future career. Sample questions were: 'From the beginning, why did you want to become an officer?', 'What does an approximate working week look like?', 'How do you experience the relationship between your work and your free time?', 
and 'What are your thoughts on your future career in the Armed Forces?'. The conversations were recorded and transcribed verbatim.

The interviews were analyzed according to the sixphase approach of coding and theme development by thematic analysis (Braun \& Clarke, 2006). This method provides a flexible and systematic technique for analyzing qualitative data. The coding process began by reading and re-reading the transcriptions to get an in-depth knowledge of the data. After that, a systematic coding process of identifying relevant patterns in the data took place, and similar codes were clustered together. After reviewing initial themes, final themes were defined and named, and analytic conclusions were drawn from data. However, the third theme is more of a progressive character, entailing some interesting and relevant topics to consider when proposing future guidelines regarding work-life balance in a military context.

\section{RESULTS}

The analysis resulted in the emergence of three main themes: coping with different loyalties, individual and organizational strategies, and concerns about the future.

\section{COPING WITH DIFFERENT LOYALTIES}

The theme highlights the divided loyalties and perceived tensions described by the newly employed officers, when attempting to deal with the different commitments and responsibilities of work and nonwork. These role-related demands and expectations involved being a reliable team member, devoted to the unit where stationed and to the organization as a whole, and concurrently, being a devoted partner and friend, spending time with and providing care and support to near ones at home. Two groups with different main approaches were identified among the officers: those who tried to balance their loyalty between work and non-work, and those who primarily expressed loyalty towards their occupational role.

All participants were highly dedicated to their work role and organization, yet almost half of them described the life outside work as the predominant and most valuable domain. They balanced between the different loyalties, trying to distribute time and engagement satisfactory between work and nonwork. One officer reflected on the importance of not identifying too much with the work role:

"There is a risk that the identity in the Armed Forces will take over. I try to separate this, so I do not identify myself with anything too much. I do not think it is healthy - At the same time, you can't play a role when you have my job. I must still be John. Af- ter all, the day I am involved in something stressful, John has to carry the burden. Not Lieutenant Wood".

Support from family and friends made it easier to handle the sometimes conflicting demands, and the officers stated that they would rather quit their jobs than be at risk of ending their relationships. Also, the officers reflected upon how their choice of occupation had affected significant others outside of work. After several years of education and training, they felt responsible for putting their partner's career on hold. From now on, they were willing to comply with their partner's plans for the future, irrespective of having to relocate or give up their military career. Two of the participants described this as follows:

"We study harder than students in civilian universities. We travel a lot. And I, who have a partner and a life at home... it was tearing me apart being away from home. We are still trying to repair our relationship after my years in the Officers' Programme".

"My future here depends on my partner's job opportunities. She's finished studying here in barely a year and a half. I feel great here and do not want to move, but if she gets a job in another place, I will sacrifice my employment and move to another regiment. Because she has sacrificed so much. I have been on a mission abroad once, and I'm going away again this winter. I have studied at the OP for three years. She's given me the opportunity to do what I want, so I'll have to adapt to her when she's done".

In contrast, the other half of the officers expressed their main loyalty and commitment towards their occupational role and the organization. They seemed unwilling to compromise in situations not compatible with their ambitions at work. This view appeared to be most significant among the officers who were stationed in remotely located units and among the officers who currently did not have a partner. Work was highly valued and gave meaning to life, as expressed by one officer: "The job is my life, I have no significant life outside of work". Additionally, four of the officers revealed that their love relationships recently had ended, since they found it difficult to get their partner to understand the demands military employment placed on them. For them, this was not just a job but more of a lifestyle:

"I would rather do something that I enjoy and feel passionate about than be somewhere else, possibly making more money and having more convenient working hours. For me, it is what you do at work that is most important, and that is why I work in the Armed Forces".

Although all participants expressed loyalty towards their work and organization, the officers trying to balance their engagement between work and non-work generally more often were in a relationship than their counterparts. Significant others in private life influenced their perceptions of work and what they valued the most in life.
Work-life balance among newly employed officers 


\section{INDIVIDUAL AND ORGANIZATIONAL STRATEGIES}

The newly employed officers were faced with a high workload from day one when starting to work in their units, resulting in stressful working conditions and frequent overtime. This situation, combined with the officers being highly ambitious and putting great demands on themselves, had complications as they tended to take on more work than manageable in the long run. Several officers had identified a need to slow down to prevent future fatigue and burnout. When finally getting home in the evenings, they felt exhausted, and time spent at home was primarily devoted to recovery, which resulted in little or no time left for socializing with family and friends:

"My free time and my social life are clearly suffering. Because I'm so exhausted when I get home, that I can't do anything but sleep. And this affects me negatively, of course. [...] In fact, my whole military career has been such a... it's difficult to get the social life to work. And during the time I was employed as a soldier, I went on international missions a couple of times. And there are not many who are interested in dating when you go away for six months and are in a war zone. Not everyone can handle it. After all, it doesn't matter if you are a soldier or if you are an officer. All respect to those who get it together, but it's always hard".

A vast majority of the officers stressed the importance of separating their work life from their nonwork life. In order to detach from their work role, they used both physical strategies, such as leaving the uniform at work when the workday was over, and psychological strategies, such as not thinking about work during free time and turning off the work phone when leaving work. The participants processed the workday during their commutes from work, to be able to "shut off" when at home.

Contrastingly, seven officers expressed a more integrative perspective on work and non-work, which resulted in the different domains blending together. These officers tended, to a greater extent than the separating officers, to work overtime and to think about work when at home. For them, taking a proactive approach and trying to get one step ahead of upcoming assignments was used as a strategy for reducing stress and tensions:

"The job almost requires working overtime. I live nearby, and sometimes I drive here in my free time to fix something. It's not healthy, but it's a paradox, because if I don't, then I'll get stressed out later".

Depending on their geographic location and organizational culture, the units provided different strategies to help officers cope with the high demands at work. These strategies consisted of formal approaches such as mentoring programs, guidance, and feedback from superiors, but also informal approaches such as social events with colleagues during free time. At units located in remote communities, spending time together substantially contributed to developing an in-depth commitment towards the unit, and to a sense of belonging to the team:

"I feel that the commanders are doing everything they can with the resources they have, and I think that is important - that someone is truly dedicated to the unit. [...] I can't put my finger on what it is, but I get a very genuine feeling from everyone who works here. They are keen that everyone should enjoy working here. And in the free time... there is not much to do here, but we have dinner parties, focusing on socializing".

The absence of supporting strategies in other units resulted in the officers experiencing high demands and constant strain, leading to an unsustainable situation at work. As the officers struggled to handle the burden of work demands by themselves, they felt abandoned by the organization, not providing the support and help they needed:

"I tried to zero my overtime. I planned a nineweek vacation this summer. No, it wasn't approved, because I had to be here. Okay. And now I have too many hours, which means they don't understand what I've done wrong. No, but I know. You haven't approved it. So now I'm on 'the red line'. I'm not allowed to have this much overtime, but I don't know when to zero my overtime".

Attempts to cope with the high workload differed among individuals, and units. Individual strategies for finding balance between work and private life were influenced by the organizational strategies, and the lack of organizational support.

\section{CONCERNS ABOUT THE FUTURE}

The officers expressed concerns about their future prerequisites to manage demands from work, and at the same time, having a sustainable life outside work. Three major concerns were identified. Firstly, the officers were concerned about coping with a constantly high strain and lack of recovery while accomplishing the job. These worries were based on how they perceived their current situation at work and the insufficient information from supervisors and the organization regarding their future careers. Most discontent were the officers working at units where supportive coping strategies were lacking:

"Some [supervisors] say that 'an officer should be able to handle this, because it will be like this at war'. Absolutely. But a war does not last for 40 or 50 years. I shouldn't be at war every day I go to work. [...] I do not want such a life, where there is constant stress every day".

Furthermore, the officers were requesting advance notice for training and changes in work schedule 
to reduce time demands and recover, and organize things at home. They experienced major problems, both at work and in private life when required to adapt to new demands on short notice:

"The most important thing, I would say, is that you know what your future holds. And by that, I mean that we have a tendency to change the organization here very often, due to the lack of staff. Holes are plugged and fires are extinguished temporarily. There is always a shortage of staff somewhere, which means that everyone works too a too high percentage of their full capacity. You do not feel good about it. You must be able to recover".

Secondly, the officers highlighted worries regarding future possibilities to combine military employment and family building. Only two officers in the sample had children, but thoughts about a future family were present among several participants. Also, in this regard, apprehensions were based on the absence of future plans and a long-term perspective on their upcoming careers:

"I am extremely nervous about having children... But we want to have children someday, and I'm not going to let my work life jeopardize my family relationship. That's out of the question! No matter how much I enjoy this occupation, I have told my partner and I tell anyone who asks that I won't let that happen".

Third, the requirements of geographical mobility for future career advancement were not appealing to the officers. The respondents felt that they had already made sacrifices when participating in officer training, and were now beginning to settle down. As mentioned in previous themes, the relocations had put a strain on their relationships and even resulted in separations. The main concerns on future mobility regarded how it would affect significant others in private life:

"It's important that the lady can cope with being alone. And maybe not everyone does. The love must be strong, so to speak, if it should last. If I am going to continue with this for the rest of my life".

In summary, the high workload combined with the lack of support and information made the newly employed officers feel anxious about their future career and their possibilities to combine work and family life. Particularly concerns about the constant strain and future family building were seen as potential reasons for leaving the military.

\section{DISCUSSION}

The aim of this study was to investigate newly employed officers' perceptions of work-life balance, and its implications for future careers. The results show that this could be understood from three overriding themes: coping with different loyalties, individual and organizational strategies, and concerns about the future. Implications for the organization and its employees are further discussed below.

Almost all of the participants in this study were fostered in the SAF during the decade of an AVF. Moskos (1977) assumed that the trend versus a more occupational direction within the military would come into force when leaving the conscription in favor of an AVF in the USA. This could, potentially, cast a shadow over our results, as all participants entered a completely new system when starting to work in the organization after their officer training. Officers were trained in an AVF organization, but employed in a conscript organization, where there could be differences regarding institutional or occupational approaches to work. Consequently Moskos (1977) postulates that individuals trained in a voluntary system generally value work-life balance more highly than those fostered in a conscript system do.

\section{COPING WITH DIFFERENT LOYALTIES}

Our participants described how they cope with different loyalties. Here, we argue that this is interlinked with the notion of multiple identities. When working in an organization, employees identify with it as part of a united group, and this group is very prominent within the military. Here, organizational values and norms become incorporated in the selfconcept as employees identify with the organization (van Knippenberg \& Sleebos, 2006).

Previously, the concept of military identity has often been measured in normative terms, e.g. culture, attitudes, values and motivation (Johansen et al., 2013), following traditional sociologist theories of Huntington (1957), Janowitz (1960), and Moskos (1977). Nonetheless, opinion is separated on how to interpret military identity, and the extent to which it affects members of a military organization (Evetts, 2003; Lock-Pullan, 2001). Our findings suggest that the officer identity is split and constructed through other facets of life, such as family and children. When identities are in conflict, the sense of a good work-life balance might be affected, which our results show.

Attempts to improve balance is closely tied to identification with roles and activities associated with being a member of work and home domains respectively. Individuals become motivated to manage borders and domains when they internalize domain values and find meaning in their responsibilities (Clark, 2000). The participants who expressed loyalty to work primarily identified with their occupational role and gave private life secondary importance. Thus, they did not perceive conflicting demands to the same extent as the officers balancing between loyalties.

According to previous research, when service is valued and supported by the spouse, the conflicting
Work-life balance among newly employed officers 
Emma Oskarsson, Johan Österberg, Joel Nilsson demands of being a loyal military member and a devoted partner become more manageable (Huffman et al., 2014). Among our balancing participants, the support rather seemed to contribute to conflict, since some officers felt indebted to their partner for encouraging their choice of occupation with all its implications. In recent years, considerable time, energy and commitment had been devoted to work, and they were now willing to even out this imbalance. This underline the challenge that most officers experience when making a career in the Armed Forces, and it is likewise a challenge for military organizations regarding training. During the current officer career system, it seems hard to facilitate a good work-life balance.

\section{INDIVIDUAL AND ORGANIZATIONAL STRATEGIES}

The participants in our sample were highly dedicated to their role as officers, and they tended to work more than manageable in the long run. In the SAF, there are formal work regulations that govern employees' financial compensation, leave, and extended leave after training and deployments. However, in some units, local deviations from these formal guidelines seemed to occur, which had consequences for the newly employed officers.

Our results show different coping strategies with work-life balance depending on geographical location and organizational prerequisites. Participants working in remote units stated that socializing was often restricted to co-workers and work-related matters outside of work. This can be a description of an institutional direction (Moskos, 1977), where life outside the unit or barracks is an integrated part of the employees' life world. In other units, though, there was a distinct separation between work and leisure time.

Significant domain members play an important role in individuals' ability to manage domains and borders (Clark, 2000), and supervisors encouraging overtime lead to a more unstable balance between the different domains. This had implications for the officers trying to separate work from private life, since it created a norm that work should always be prioritized. For participants with a more integrative perspective between work and private life, temporal and psychological borders between domains became weak and flexible, and they tended to work long hours in order to reduce work-related stress.

For many participants, the high workload and absence of organizational support lead to a lack of recovery and little or no time left for a social life outside work, which indicates a time-based and strain-based conflict. This could negatively impact retention, as the feeling of inadequacy can have a corrosive effect on job satisfaction and, in turn, retention. To avoid putting strain on newly employed officers, the SAF needs to make sure that the formal work regulations are followed.

\section{CONCERNS ABOUT THE FUTURE}

The SAF has gone from an extensive, conscript-based defense force to a small, volunteer-based force and back to conscription. The SAF is in a period of growth, which probably will lead to job security for those entering the organization. However, the concerns among our participants are in another direction. Those concerns deal with coping with a constantly high strain, and with commuting and the necessity to move around as the officer profession requires mobility. This in turn can worsen work-life balance and make many officers leave the organization.

From the time when our participants entered the organization, their focus on what is important in life has shifted from being highly dedicated to work, to wanting a balanced life with a family in the future. As previously pointed out by Segal (1986), when years of career building coincide with years of family building, adaptability becomes problematic. During the course of a military career, deployments and geographic mobility are inevitable to advance in the officer profession, and our participants are very much aware of this.

For some officers, previous relocations had resulted in major personal sacrifices regarding their relationships, even separations. The officers who had a partner felt guilty for frequently being away, and the officers currently not in a relationship had a hard time finding someone who could accept the demands that the military career placed on them. Thus, concerns about future prerequisites to combine work and family were based on interpretations about their previous and current, very demanding, work situation. In addition, a long-term perspective on their upcoming careers, which was much sought after, was lacking.

Concerns about the future highlight the need for information and support. Research among military personnel shows that a high workload contributes to work-life conflict (Huffman et al., 2014), and that separations from home contribute to reduced relationship satisfaction and increased turnover intentions (Andres et al., 2012). Thoughts about leaving employment gradually make the individual psychologically detached from work, and increase the likelihood of resigning. There is a strong relationship between considering leaving one's employment and then actually doing so. The fact that the SAF is growing again also puts focus on the burden of work within the organization. As ambitious individuals in a growing organization with many vacancies tend to work a lot and place high demands on themselves, it seems that support from the SAF is unsatisfactory, which in turn can lead to burnout and increased intentions to leave. 


\section{CONCLUSIONS}

In order to retain qualified personnel, the SAF should provide support and create conditions that help employees balance work and non-work. Greater attention needs to be put on the different loyalties, and how these are interlinked with identities, which negatively affect the newly employed officers. A career in the Armed Forces will inevitably involve a reduced work-life balance, and our results show that the newly employed officers are highly aware of this. To ease the pressure, the SAF could be clearer about the expectations on their new employees. Although conflicting demands cannot be entirely eliminated, they certainly can be reduced.

\section{LIMITATIONS AND FUTURE RESEARCH}

There are some limitations that need to be addressed. First, the sample consisted of a limited number of participants, and the results should therefore be seen as explorative. Secondly, airborne and naval units were not represented in this study, so the results cannot be applied to the whole organization. Future research on work-life balance in a military context should include these branches. The newly employed officers were relatively young and at the beginning of their military careers. Thoughts about work-life balance could be of a different nature at a later stage in life. By studying officers with families including dependent children, a different perspective on worklife balance can be obtained. Furthermore, future research could focus on perceptions of work-life balance among military members' partners.

\section{RefERENCES}

Allen, T. D., Johnson, R. C., Saboe, K. N., Cho, E., Dumani, S., \& Evans, S. (2012). Dispositional variables and work-family conflict: a meta-analysis. Journal of Vocational Behavior, 80, 17-26. https:// doi.org./10.1016/j.jvb.2011.04.004

Anderson, J., \& Goldenberg, I. (2019). Balancing act: The demands of family, military service, and civilian employment for reservists. In R. Moelker, M. Andres, \& N. Rones (Eds.), The politics of military families: State, work organizations, and the rise of the negotiation household (pp. 152-168). Routledge.

Andres, M., Moelker, R., \& Soeters, J. (2012). The workfamily interface and turnover intentions over the course of project-oriented assignments abroad. International Journal of Project Management, 30, 752 759. https://doi.org/10.1016/j.ijproman.2012.01.006

Braun, V., \& Clarke, V. (2006). Using thematic analysis in psychology. Qualitative $R e$ - search in Psychology, 3, 77-101. https:// doi.org/10.1191/1478088706qp063oa

Casper, W. J., Vaziri, H., Wayne, J. H., DeHauw, S., \& Greenhaus, J. (2018). The jingle-jangle of worknonwork balance: a comprehensive and metaanalytic review of its meaning and measurement. Journal of Applied Psychology, 103, 182-214. https:// doi.org/10.1037/apl0000259

Clark, S. C. (2000). Work/family border theory: a new theory of work/family balance. Human Relations, 53, 747-770. https://doi.org/10.1177/0018726700536001

Dupré, K. E., \& Day, A. L. (2007). The effects of supportive management and job quality on the turnover intentions and health of military personnel. Human Resource Management, 46, 185-201. https:// doi.org/10.1002/hrm.20156

Evetts, J. (2003). Explaining the construction of professionalism in the military: History, concepts and theories. Revue Française De Sociologie, 44, 759-776. https://doi.org/10.2307/3323236

Fors Brandebo, M., Österberg, J., \& Berglund, A. K. (2019). The Impact of constructive and destructive leadership on soldier's job satisfaction. Psychological Reports, 122, 1068-1086. https:// doi.org/10.1177/0033294118771542

French, K. A., Dumani, S., Allen, T. D., \& Shockley, K. M. (2018). A meta-analysis of work-family conflict and social support. Psychological Bulletin, 144, 284-314. https://doi.org/10.1037/bul0000120

Frone, M. R., Yardley, J. K., \& Markel, K. S. (1997). Developing and testing an integrative model of the workfamily interface. Journal of Vocational Behavior, 50, 145-167. https://doi.org/10.1006/jvbe.1996.1577

Greenhaus, J. H., Collins, K. M., \& Shaw, J. D. (2003). The relation between work-family balance and quality of life. Journal of Vocational Behavior, 63, 510-531. https://doi.org/10.1016/S0001-8791(02)00042-8

Greenhaus, J. H., \& Beutell, N. J. (1985). Sources of conflict between work and family roles. Academy of Management Review, 10, 76-88. https:// doi.org/10.5465/amr.1985.4277352

Hedlund, E. (2013). Civil-military control over the Swedish military profession: an analysis from the perspective of officer rank and officer education. Armed Forces \& Society, 39, 135-157. https:// doi.org/10.1177/0095327X11426256

Hill, E. J., Hawkins, A. J., Ferris, M., \& Weitzman, M. (2001). Finding an extra day a week: The positive influence of perceived job flexibility on work and family life balance. Family Relations, 50, 49-58. https://doi.org/10.1111/j.1741-3729.2001.00049.x

Huffman, A. H., Culbertson, S. S., \& Castro, C. A. (2008). Family-friendly environments and U.S. Army soldier performance and work outcomes. Military Psychology, 20, 253-270. https:// doi.org/10.1080/08995600802345162

Huffman, A. H., Payne, S. C., Koehly, L. M., Culbertson, S. S., \& Castro, C. A. (2014). Examining time
Work-life balance among newly employed officers 
Emma Oskarsson, Johan Österberg, Joel Nilsson demands and work-family conflict on psychological distress. Military Behavioral Health, 2, 26-32. https://doi.org/10.1080/21635781.2013.844662

Huntington, S. (1957). The soldier and the state: The theory and practice of civil-military relations. Harvard University Press.

Janowitz, M. (1960). The professional soldier. Free Press.

Johansen, R. B., Laberg, J. C., \& Martinussen, M. (2013). Measuring military identity: Scale development and psychometric evaluations. Social Behavior and Personality, 41, 861-880. https:// doi.org/10.2224/sbp.2013.41.5.861

Lock-Pullan, R. (2001). "And the wall came trumbling down": The current debate on the changing nature of the military professional. Defence Studies, 1, 122-132. https://doi.org/10.1080/714000039

MacDermid, W. S., \& Southwell, K. (2011). Military families: Extreme work and extreme "workfamily". Annals of the American Academy of Political and Social Science, 638, 163-183. https:// doi.org/10.1177/0002716211416445

Moskos, C. C., Jr (1977). From institution to occupation: Trends in military organization. Armed Forces \& Society, 4, 41-50. https:// doi.org/10.1177/0095327X7700400103

Österberg, J., Oskarsson, E., \& Nilsson, J. (submitted). Perceptions of officer training among newly employed officers and specialist officers in the Swedish Armed Forces - a qualitative study. Manuscript submitted for publication.

Österberg, J., \& Nilsson, J. (2019). A diary-based case study in the development of unit cohesion during basic training in the Swedish Air Force. Res Militaris, 9, 1029926.

Österberg, J., \& Rydstedt, L. W. (2018). Job satisfaction among Swedish soldiers: Applying the job characteristics model to newly recruited military personnel. Military Psychology, 30, 302-310. https://doi.org/10.1080/08995605.2018.1425585

Österberg, J., Rydstedt, L. W., Kleiven, J., \& Fors Brandebo, M. (2017). The path to job satisfaction. Applying the theory of purposeful behavior to military conditions. Journal of Defense Resources Management, 8, 27-42.

Pickering, D. (2017). Balancing the demands of military and family life: Understanding the challenges faced by military personnel. In A. Maclntyre, D. Lagacé-Roy, \& D. R. Lindsay (Eds.), Global views on military stress and resilience (pp. 79-101). Canadian Defence Academy Press.

Pleck, J. H., Staines, G. L., \& Lang, L. (1980). Conflicts between work and family life. Monthly Labor Review, 103, 29-32.

Rydstedt, L. W., \& Österberg, J. (2013). Psychological characteristics of Swedish mandatory enlisted soldiers volunteering and not volunteering for international missions: an exploratory study. Psychological Reports, 112, 678-688. https:// doi.org/10.2466/17.02.PR0.112.2.678-688

Sachau, D. A., Gertz, J., Matsch, M., Johnson Palmer, A., \& Englert, D. (2012). Work-life conflict and organizational support in a military law enforcement agency. Journal of Police and Criminal Psychology, 27, 63-72. https://doi.org/10.1007/s11896011-9095-x Segal, M. W. (1986). The military and the family as greedy institutions. Armed Forces \& Society, 13, 9-38. https://doi.org/10.1177/0095327X8601300101

Strand, S., \& Berndtsson, J. (2015). Recruiting the "enterprising soldier": Military recruitment discourses in Sweden and the United Kingdom. Critical Military Studies, 1, 233-248. https:// doi.org/10.1080/23337486.2015.1090676

van Knippenberg, D., \& Sleebos, E. (2006). Organizational identification versus organizational commitment: Self-definition, social exchange, and job attitudes. Journal of Organizational Behavior, 27, 571-584. https://doi.org/10.1002/job.359

Voydanoff, P. (2005). Consequences of boundaryspanning demands and resources for work-tofamily conflict and perceived stress. Journal of $\mathrm{Oc}^{-}$ cupational Health Psychology, 10, 491-503. https:// doi.org/10.1037/1076-8998.10.4.491

Vuga, J., \& Juvan, J. (2013). Work-family conflict between two greedy institutions - the family and the military. Current Sociology, 61, 1058-1077. https://doi.org/10.1177/0011392113498881

Weber, M., \& Österberg, J. (2015). A principal component analysis of Swedish conscripts' values and attitudes towards their military education. Res Militaris, 5, 1022278. 